Article

\title{
Investigating the Influence of Light Shelf Geometry Parameters on Daylight Performance and Visual Comfort, a Case Study of Educational Space in Tehran, Iran
}

\author{
Mohammad Hossein Moazzeni ${ }^{1, *}$ and Zahra Ghiabaklou ${ }^{2}$ \\ 1 Department of Engineering, Science and Research Branch Tehran (Alborz), Islamic Azad University, \\ Karaj 3148635731, Iran \\ 2 Faculty of Fine Arts, School of Architecture, University of Tehran, Tehran 14395-515, Iran; \\ ghiabaklou@ut.ac.ir \\ * Correspondence: m_moazzeni@Aol.com; Tel.: +98-9127489707
}

Academic Editor: Ravi Srinivasan

Received: 6 May 2016; Accepted: 6 July 2016; Published: 13 July 2016

\begin{abstract}
Daylight can be considered as one of the most important principles of sustainable architecture. It is unfortunate that this is neglected by designers in Tehran, a city that benefits from a significant amount of daylight and many clear sunny days during the year. Using a daylight controller system increases space natural light quality and decreases building lighting consumption by $60 \%$. It also affects building thermal behavior, because most of them operate as shading. The light shelf is one of the passive systems for controlling daylight, mostly used with shading and installed in the upper half of the windows above eye level. The influence of light shelf parameters, such as its dimensions, shelf rotation angle and orientation on daylight efficiency and visual comfort in educational spaces is investigated in this article. Daylight simulation software and annual analysis based on climate information during space occupation hours were used. The results show that light shelf dimensions, as well as different orientations, especially in southern part, are influential in the distribution of natural light and visual comfort. At the southern orientation, increased light shelf dimensions result in an increase of the area of the work plane with suitable daylight levels by $2 \%-40 \%$ and a significant decrease in disturbing and intolerable glare hours.
\end{abstract}

Keywords: daylight; visual comfort; educational space; light shelf; daylight simulation

\section{Introduction}

Daylight can be considered as one of the main factors of sustainable architecture. Light is one of the effective strategies in building energy optimization. Using a developed system of daylight designing decreases building's electrical consumption significantly. It also affects indoor lighting quality [1]. Using daylight has many economic and bio-environmental advantages [2]. Electric energy consumption is the most important effective factor in buildings' carbon emission [3], which consist 30-40 percent of the total energy consumed in commercial buildings [4]. By the developed designing of daylight, cooling load decreases significantly [5]. Weak designing of the buildings' natural light and improper internal air quality caused negative lasting influences on residents' health. Daylight quality is one of the most important influential factors for students' performance. The literature shows not only the significant influence of daylight on the visual system, but also its positive role in increasing physical and mental health and decreasing stress. Using daylight is the base and infrastructure of sustainable architecture of high efficiency schools. By taking advantage of daylight in schools or the educational environment, classroom light amount and physical health level will increase, stress will 
decrease, success will improve and, as a result, students efficiency increases as observed and shown in the results of various research works [6-8]. The light shelf is one of the passive systems for daylight controlling. In fact, the light shelf is a horizontal plate made of light-colored and reflective materials that reflects daylight and is placed above human eye level in the upper half of the window. It decreases the light severity near the window and increases the light penetration depth; distributes daylight more properly in space and also decreases glare by reflecting daylight to the ceiling and reflecting it into the space. Most of the time, the light shelf is accompanied with shading or an external shelf to perform better [9]. Some of the most important parts of the light shelf performance have been studied in Table 1, which include some of technical issues and considerable data.

Table 1. Sample of conducted studies on the light shelve.

\begin{tabular}{|c|c|c|c|c|c|}
\hline Study & Focus & $\begin{array}{c}\text { Light Shelf } \\
\text { Data }\end{array}$ & $\begin{array}{l}\text { Different } \\
\text { Material }\end{array}$ & $\begin{array}{l}\text { Daylight } \\
\text { Simulation }\end{array}$ & Measurement \\
\hline $\begin{array}{l}\text { Waary and } \\
\text { Hael [10] }\end{array}$ & $\begin{array}{l}\text { Enhancing daylight and } \\
\text { improving energy } \\
\text { through the utilization of } \\
\text { light shelves }\end{array}$ & $\begin{array}{l}\text { Light shelf } \\
\text { heights, } \\
\text { exterior and } \\
\text { interior length }\end{array}$ & No & Yes & No \\
\hline $\begin{array}{l}\text { Claros and } \\
\text { Soler [11] }\end{array}$ & $\begin{array}{l}\text { Influence of light shelf } \\
\text { and model reflectance on } \\
\text { light shelf performance }\end{array}$ & Fixed & Yes & No & Yes \\
\hline Meresi [12] & $\begin{array}{l}\text { Evaluating daylight } \\
\text { performance of light } \\
\text { shelves combined with } \\
\text { external blinds in } \\
\text { south-facing classrooms } \\
\text { in Athens }\end{array}$ & $\begin{array}{l}\text { Light shelf } \\
\text { width, heights, } \\
\text { rotation }\end{array}$ & Yes & Yes & Yes \\
\hline Aghemo et al. [13] & $\begin{array}{l}\text { The approach to } \\
\text { daylighting by scale } \\
\text { models and sun and } \\
\text { sky simulators }\end{array}$ & $\begin{array}{l}\text { Light shelf } \\
\text { compare with } \\
\text { shading }\end{array}$ & No & No & Yes \\
\hline $\begin{array}{l}\text { Brotas and } \\
\text { Rusovan [14] }\end{array}$ & $\begin{array}{l}\text { Parametric daylight } \\
\text { envelope }\end{array}$ & $\begin{array}{l}\text { Light shelf } \\
\text { compare with } \\
\text { shading }\end{array}$ & No & Yes & No \\
\hline $\begin{array}{l}\text { Ochoa and } \\
\text { Capeluto [15] }\end{array}$ & $\begin{array}{l}\text { Evaluating visual } \\
\text { comfort and } \\
\text { performance of three } \\
\text { natural lighting systems } \\
\text { for deep office buildings } \\
\text { in highly } \\
\text { luminous climates }\end{array}$ & $\begin{array}{l}\text { Light shelf } \\
\text { length and } \\
\text { compare with } \\
\text { anidolic system }\end{array}$ & No & Yes & Yes \\
\hline $\begin{array}{c}\text { Lim and } \\
\text { Ahmad [16] }\end{array}$ & $\begin{array}{l}\text { The effects of direct } \\
\text { sunlight on light shelf } \\
\text { performance under } \\
\text { tropical sky }\end{array}$ & $\begin{array}{l}\text { Numbers and } \\
\text { internal light } \\
\text { shelf length }\end{array}$ & No & No & Yes \\
\hline $\begin{array}{l}\text { Sanati and } \\
\text { Utzinger [17] }\end{array}$ & $\begin{array}{l}\text { The effect of window } \\
\text { shading design on } \\
\text { occupant use of blinds } \\
\text { and electric lighting }\end{array}$ & $\begin{array}{l}\text { Number, } \\
\text { rotation, } \\
\text { Interior light } \\
\text { shelf }\end{array}$ & No & Yes & Yes \\
\hline $\begin{array}{l}\text { Ochoa and } \\
\text { Capeluto [18] }\end{array}$ & $\begin{array}{l}\text { Strategic } \\
\text { decision-making for } \\
\text { intelligent buildings: } \\
\text { comparative impact of } \\
\text { passive design strategies } \\
\text { and active features in a } \\
\text { hot climate }\end{array}$ & $\begin{array}{l}\text { Light shelf } \\
\text { length, height, }\end{array}$ & No & Yes & No \\
\hline
\end{tabular}


Table 1. Cont.

\begin{tabular}{clcccc}
\hline Study & \multicolumn{1}{c}{ Focus } & $\begin{array}{c}\text { Light Shelf } \\
\text { Data }\end{array}$ & $\begin{array}{c}\text { Different } \\
\text { Material }\end{array}$ & $\begin{array}{c}\text { Daylight } \\
\text { Simulation }\end{array}$ & Measurement \\
\hline Freewan [19] & $\begin{array}{l}\text { Maximizing the light } \\
\text { shelf performance by } \\
\text { interaction between light } \\
\text { shelf geometries and a } \\
\text { curved ceiling }\end{array}$ & $\begin{array}{c}\text { Horizontal and } \\
\text { curve light } \\
\text { shelf }\end{array}$ & No & Yes & No \\
\hline $\begin{array}{l}\text { Ponmalar and } \\
\text { Ramesh [20] }\end{array}$ & $\begin{array}{l}\text { Energy efficient building } \\
\text { design and estimation of } \\
\text { energy savings from } \\
\text { daylighting in Chennai }\end{array}$ & Fixed & Yes & Yes & No \\
\hline Kim et al. [21] & $\begin{array}{l}\text { Comparative advantage } \\
\text { of an exterior shading } \\
\text { device in thermal } \\
\text { performance for } \\
\text { residential buildings }\end{array}$ & Fixed & No & Yes \\
\hline
\end{tabular}

The conducted studies investigating and measuring light shelf efficiency have almost all been done for a determined date and have investigated daylight by simulation or measurement. The light shelf has been less implemented in the annual examination of daylight and visual comfort in educational spaces. Furthermore, limited numerical studies on the form of light shelf actually exist for Iran. This article shows that according to the literature, the hypothesis that the light shelf increases natural light is confirmed and proven to be very useful for educational spaces. The purpose of this article is to examine the light shelf dimensions' and orientations' influence on daylight performance and visual comfort during the year by using daylight simulation and the developed analysis in an educational space in Tehran. The article is going to answer the following questions.

How much do internal and external light shelf dimensions affect classroom annual daylight in Tehran? Do the light shelf external rotation angle and window orientation affect the annual natural light performance rate? Does the glare possibility decrease by using the light shelf, which plays an important role in the visual comfort of the students?

\section{Methodology}

\subsection{The Characteristics of the Studied Educational Space}

In this article, the light shelf was studied by simulating a room used as an educational place. The classroom is located in Tehran $\left(35^{\circ} 41^{\prime} \mathrm{N}, 51^{\circ} 25^{\prime} \mathrm{E}\right)$. Dimensions and details are based on standard organization and work national regulations [22], which are set as seven meters width, eight meters length and $3.5 \mathrm{~m}$ height. This classroom has been equipped with a $7-\mathrm{m}^{2}$ window in the south part with a $50 \%$ Window to Wall Ratio (WWR) in the length view, in the center of the view and in the southern part located $1.3 \mathrm{~m}$ higher than the floor. The window condition is assumed with no operable interior blinds or shading systems. The light shelf is also located $2.40 \mathrm{~m}$ higher than the floor (Figure 1). The chosen shelf dimensions for simulation are such that external (Ext) light shelves of 0.3-0.6-0.9 and $1.2 \mathrm{~m}$ each are calculated and analyzed considering internal (Int) shelves of 0-0.3-0.6-0.8 and $1 \mathrm{~m}$, also by selecting one of the samples; the external light shelf is calculated in the horizon direction in five angles of 0-5-10-20-30 degrees. The mentioned variables are also calculated for four main geographical orientations. A total of 100 different models of the light shelf were evaluated and simulated. The supposed classroom materials are such that a double glazing window with a visible light transmission rate of $80 \%$ is used. In daylight simulation, the rate of the reflective light from the material's surface and the kinds of materials are important. Here, the diffuse reflection kind is used. The other surfaces of the model are summarized in Table 2. For choosing the rate of this reflection, beside the work regulation and Iranian standard [23,24], it also corresponded with IESNA [24]. 
Table 2. The kind and amount of reflection on the surfaces of the studied classroom.

\begin{tabular}{cc}
\hline Model Structure & Diffused Reflection Percentage \\
\hline Walls & $50 \%$ \\
Ceiling & $90 \%$ \\
Floor & $20 \%$ \\
Glass & Double glazing, $80 \%$ light transmission \\
Light shelf & $90 \%$ \\
Earth surface & $20 \%$ \\
Table and chair & $50 \%$ \\
\hline
\end{tabular}

For analyzing daylight, some sensors were placed $0.75 \mathrm{~m}$ above the floor. This surface is called the work plane. Six hundred and seventy four (674) sensors (dots embedded for daylight analysis) were placed in the classroom with $0.5-$ and $0.25-\mathrm{m}$ length intervals. The calculated information on these dots is based on height. The mentioned cases, such as classroom dimensions, light shelf location, sensor location and work plane, are seen in Figure 1.

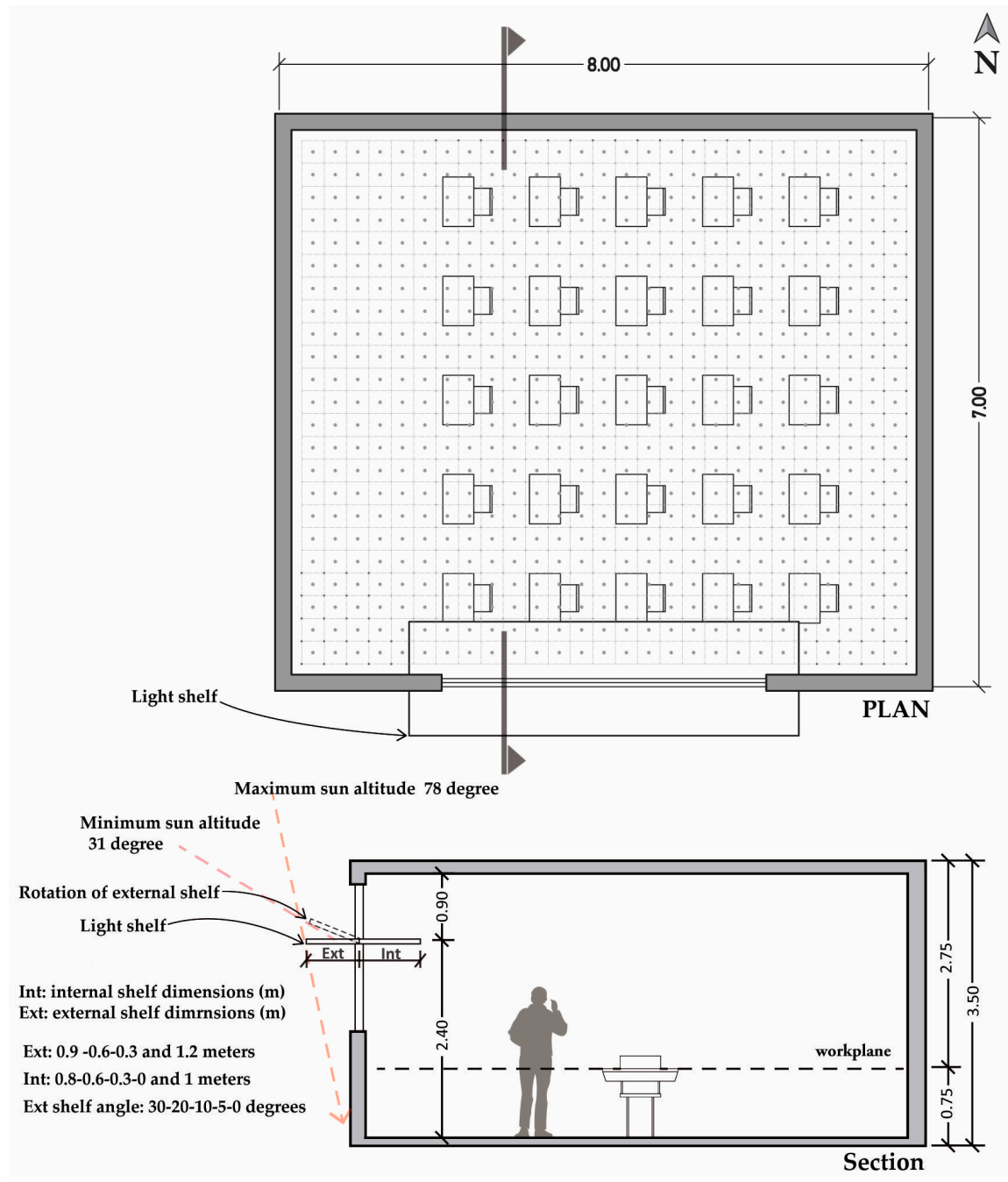

Figure 1. Classroom dimensions, work plane and shelf location; in addition to the southern orientation, northern, eastern and western orientations have also been studied. 


\subsection{Daylight Simulation Software}

Today, daylight simulation is one of the most common simulations in architecture designing process. The results of the diagrams presented by Reinhart show that daylight simulator software is effective and progressive at the primary levels of designing in comparison to other daylight analysis methods used by designers and engineers [25]. According to the visual nature of this kind of simulation, these software programs are more commonly used among designers in comparison with thermal and energy modeling software. One of the most important daylight simulation software among researchers is Radiance, which uses a ray-tracing method for simulation [26]. Unlimited space geometry and different materials in daylight simulation are among the Radiance software advantages. The proper abilities of this software, now led by the Lawrence Berkeley National Laboratory (LBNL) research team, encouraged many types of software to use it as a daylight simulation in combination with or besides other software. According to a survey, among 185 participants from 27 countries, nearly $50 \%$ chose Radiance-based software among more than 40 daylight software introduced [27]. Different validations have also been done for Radiance [28-31]. DIVA-for-Rhino software is a developed daylight and energy modeling plug-in for the Rhinoceros [32] software, which analyzes and simulates daylight and visual comfort based on Radiance and Daysim [33]. Here, also DIVA-for-Rhino software is used because of the progressive facilities and accessibility to a comprehensive collection of daylight and visual comfort analysis [34,35]. Determination of daylight simulation parameters for radiance is among the most important parts of simulation; the parameters are shown in Table 3. The most important parameter is the ambient bounces $(\mathrm{ab})$ amount, which shows the number of daylight radiance reflections. To achieve exact results based on the examined sample, ab is considered to be equaled to 5 [36-38]. A lesser or the default amount for the software will result in wrong and unreal findings for light shelf analysis.

Table 3. The amount of applied parameters for radiance daylight simulation.

\begin{tabular}{cccccc}
\hline $\begin{array}{c}\text { ab (Ambient } \\
\text { Bounces) }\end{array}$ & $\begin{array}{c}\text { ad (Ambient } \\
\text { Divisions) }\end{array}$ & $\begin{array}{c}\text { as (Ambient } \\
\text { Sampling) }\end{array}$ & $\begin{array}{c}\text { aa (Ambient } \\
\text { Accuracy) }\end{array}$ & $\begin{array}{c}\text { ar (Ambient } \\
\text { Resolution) }\end{array}$ & $\begin{array}{c}\text { dt (Direct } \\
\text { Threshold) }\end{array}$ \\
\hline 5 & 1000 & 20 & 0.1 & 300 & 0 \\
\hline
\end{tabular}

\subsection{The Quality of Daylight Simulation Results Analysis}

Considering the kind of calculations, the simulation results analysis is divided into two sets of dynamic and static. Static calculation is a kind of calculation assessed in a special time and fixed conditions, whereas dynamic calculation is assessed during the year, based on annual weather information and changing conditions. Using these analyses and comparing daylight systems' options in different models with different conditions pave the way for choosing proper and optimal option by considering daylight $[39,40]$. Daylight availability, developed by Reinhart, is the kind of analysis used in this article. This analysis is a combination of "Daylight Autonomy" (DA) and "Useful Daylight Illumination" (UDI) and has a similar, but more suitable function [41,42]. Daylight availability analysis determines the space usage (occupation), the work hour (in this article, from 8:00 a.m.-6:00 p.m.) and the minimum received amount of daylight for classroom in work plane (in this article, 500 lux); then, it investigates and calculates the daylight perceived percent in sensors embedded in the work plane during the year. This measurement is done according to input, simulation results and annual average weather information, such as sky status during the year based on the Radiance software by Daysim. The percentage amount of work time (8:00 a.m.-6:00 p.m.) for which nodes received 500 lux or more during the year is shown in colored degrees. Now, using the amount of the nodes' received percentage, "overlit" dots will be determined; dots having 10-times more than the determined lux (500 lux) in during at least $5 \%$ of the occupation time. "Overlit" dots are shown by red color; glaring is more probable on these dots. Furthermore, nodes having $0 \%-49 \%$ of the determined work time lux or more are called "partial daylit" dots, and dots having between $50 \%$ and $100 \%$ are called "suitable and enough daylit" (Figure 2). To gain more accuracy using Excel, this study analyzes the data of daylight 
availability by three classifications of "partial daylit, daylit and overlit" and calculates each node received percentage compared to other sensors, and the percentages are shown in the three mentioned intervals. In fact, a space having a greater daylit percentage is the most daylight efficient, which has less partial daylit and overlit (Figure 3). To better investigate the efficiency of daylight in educational systems during the year and to analyze and examine light shelf states more, this kind of analysis was used. This calculation method was also used in valid research works [43,44].

\section{Results}

Simulation and analysis results will be discussed here and are divided into two sections of daylight and visual comfort.

\subsection{Daylight Simulation Results}

\subsubsection{Southern Orientation}

The results of light shelf simulation and analysis at the southern orientation are shown as an image and colored degree on the work plane surface in Figure 2. The last row of the table is related to the rotation angle changes. In order to have a better and more precise comparison, the gained qualitative data are shown in diagrammatic format (Figure 3). As you can see, these information is placed in three mentioned intervals of partial daylit, daylit and overlit. The first model that lacks the light shelf benefits (base model) is $48 \%$ daylit, $51 \%$ overlit and lacks partial daylit. This causes many problems, such as glaring and increasing the expense of cooling the building. By increasing the shelf internal and external dimensions, the amount overlit will decrease, and suitable light increases in the space. As in the sample (Ext 0.3_Int 0.8), daylit increased up to $22 \%$ and overlit decreased up to $23 \%$ compared to the model without the shelf. By comparing to Figure 2, it is obvious that most of these changes have happened in the middle part of the classroom. This daylit increase is accompanied with the shelf internal and external dimensions' increase. As for the sample, the shelf external dimension is 1.2 meters and the shelf internal dimension is one meter (Ext 1.2_Int 1), the amount of suitable daylit is $87 \%$ and overlit reaches $12 \%$, which suitable daylit increased up to $40 \%$ compared to the without the shelf classroom. Although using these dimensions has its own limitations, this increase is accompanied with the shelf light dimensions' increase, which provides a wide surface for daylight reflection onto the ceiling. By changing the external shelf angle relative to the horizon, no significant difference occurs, and zero angles are more efficient than a 30-degree angle; the 30 degree angle causes a small proper daylight decrease. 


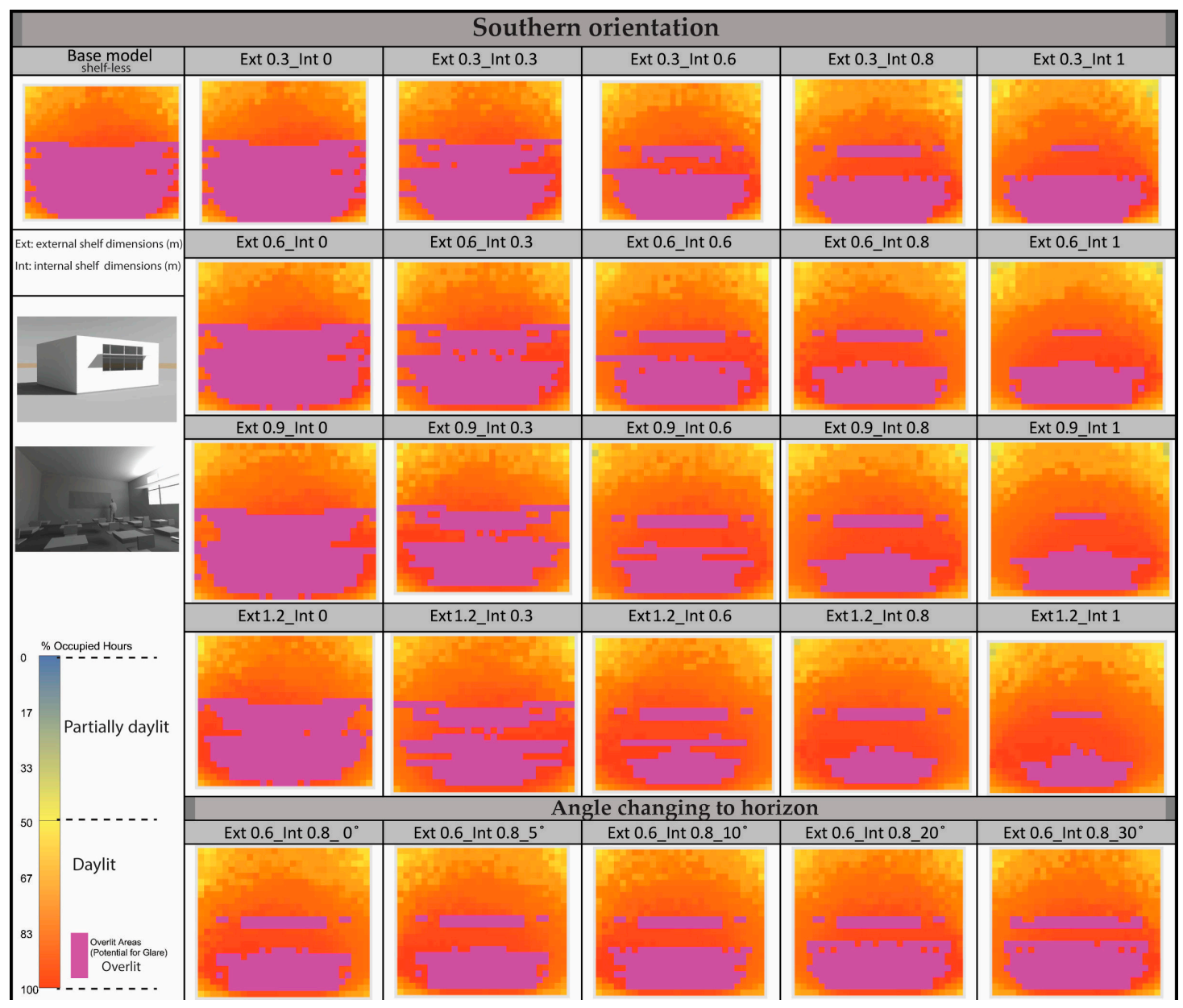

Figure 2. The results of daylight availability analysis for light shelf southern orientation in the three mentioned intervals and the colored degree format on the work plane surface.

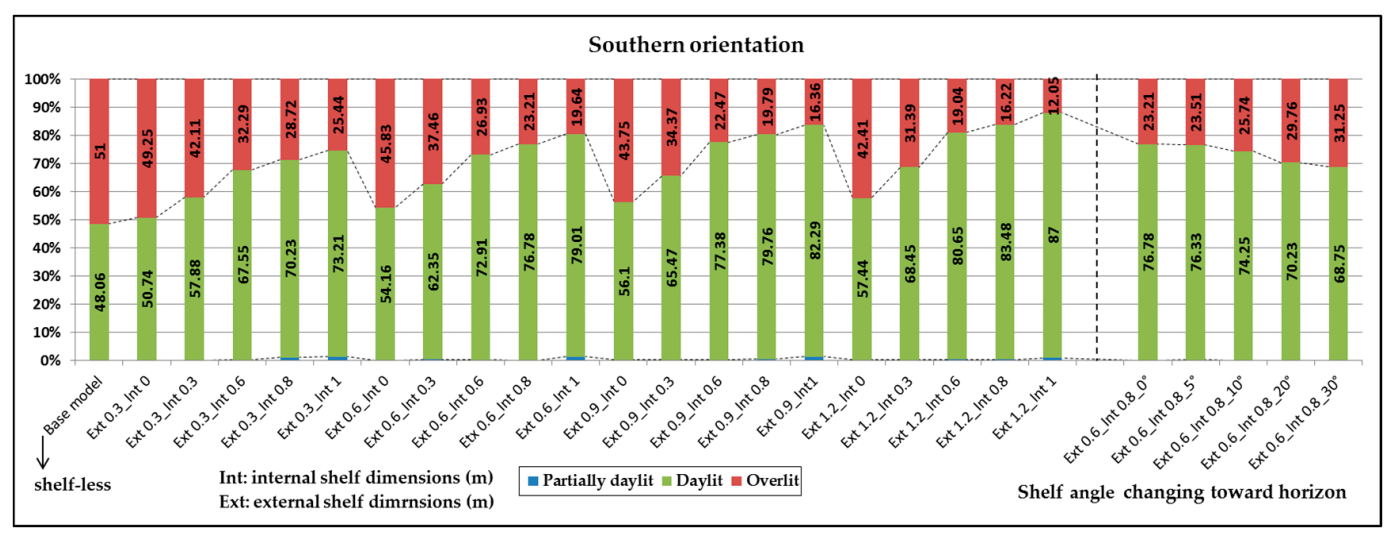

Figure 3. The results of daylight availability analysis for the southern orientation of the light shelf in the three mentioned intervals.

\subsubsection{Northern Orientation}

In the northern orientation of the classroom, there is a little amount of overlit (just when direct sunlight exists in this orientation, early sunset and sunrise in the summer), which does not have significant influence on the classroom annual results. As is seen in Figure 4, there is a little overlit because of the lack of direct sunlight in the space. There is $5 \%$ in the shelf-less model, $25 \%$ partial daylit 
and $70 \%$ suitable daylit in this model. This section's results are unlike the southern orientation; as the shelves' internal and external dimensions increase, space daylit decreases. This decrease happens because the shelf prevents indirect sunlight entrance. Direct sunlight does not exist in this part; therefore, the only daylight source is indirect sunlight. When the external shelf dimension is 3.0 and the internal shelf dimension is 8.0, the partial daylit and improper daylight have increased up to $18 \%$ in comparison with the shelf-less scenario. When the external shelf dimension is 1.2 and the internal shelf dimension is one meter, at the end of the classroom, partial daylit and insufficient day light increase up to $25 \%$. By changing shelf angle relative to the horizon, partial daylit decreases, but it is not significant because of the entrance of more light into the space. For the 30 degree angle, partial daylit reaches $41 \%$, which is different from zero degrees by $4 \%$.

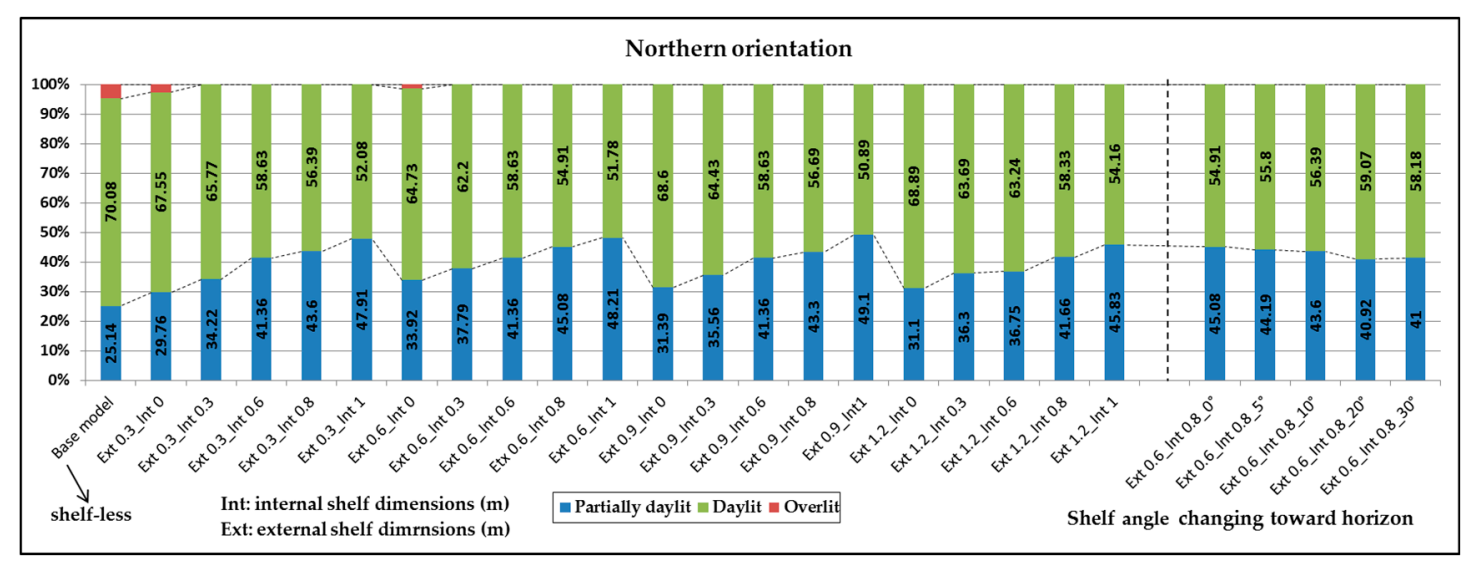

Figure 4. The results of daylight availability analysis for the light shelf in the northern orientation in the three mentioned intervals.

\subsubsection{Eastern and Western Orientations}

The results of eastern and western orientations are nearly the same, as the sun movement is symmetric [43]. These parts have indirect sunlight (because of different sunshine angles during these hours) during the day, except some hours of the day (sunset and sunrise). As is observed in Figure 5, the results of the function of the shelf-less model in eastern orientation are such that it has $60 \%$ suitable daylit, $37 \%$ overlit and 5\% partial daylit. Generally, changing the light shelf dimensions and increasing the internal and external light shelf dimensions decreases overlit (because of the change of the sun ray angle encountering the shelf and casting a shadow) and increases daylit and partial daylit. The reason for the partial daylight increase is lacking direct sunlight to be reflected and preventing the penetration of indirect light by the shelf in other hours. On the other hand, by increasing the light shelf as in the following sample, when the external shelf is $1.2 \mathrm{~m}$ and the internal shelf is $0.8 \mathrm{~m}$, daylit increases up to $80 \%$, which is $20 \%$ higher than the basic shelf-less model; overlit decreases to $12 \%$; and partial daylit will be $8 \%$. In fact, the internal and external wide surfaces of the shelf increase the suitable daylit. While shining in the room because of the low solar altitude, more daylight enters the end and middle parts of the room. Changing the light shelf angle relative to the horizon increases daylit and overlit a little and decreases partial daylit, which causes an increase in direct sunlight entrance because of the increasing angle relative to the horizon. 


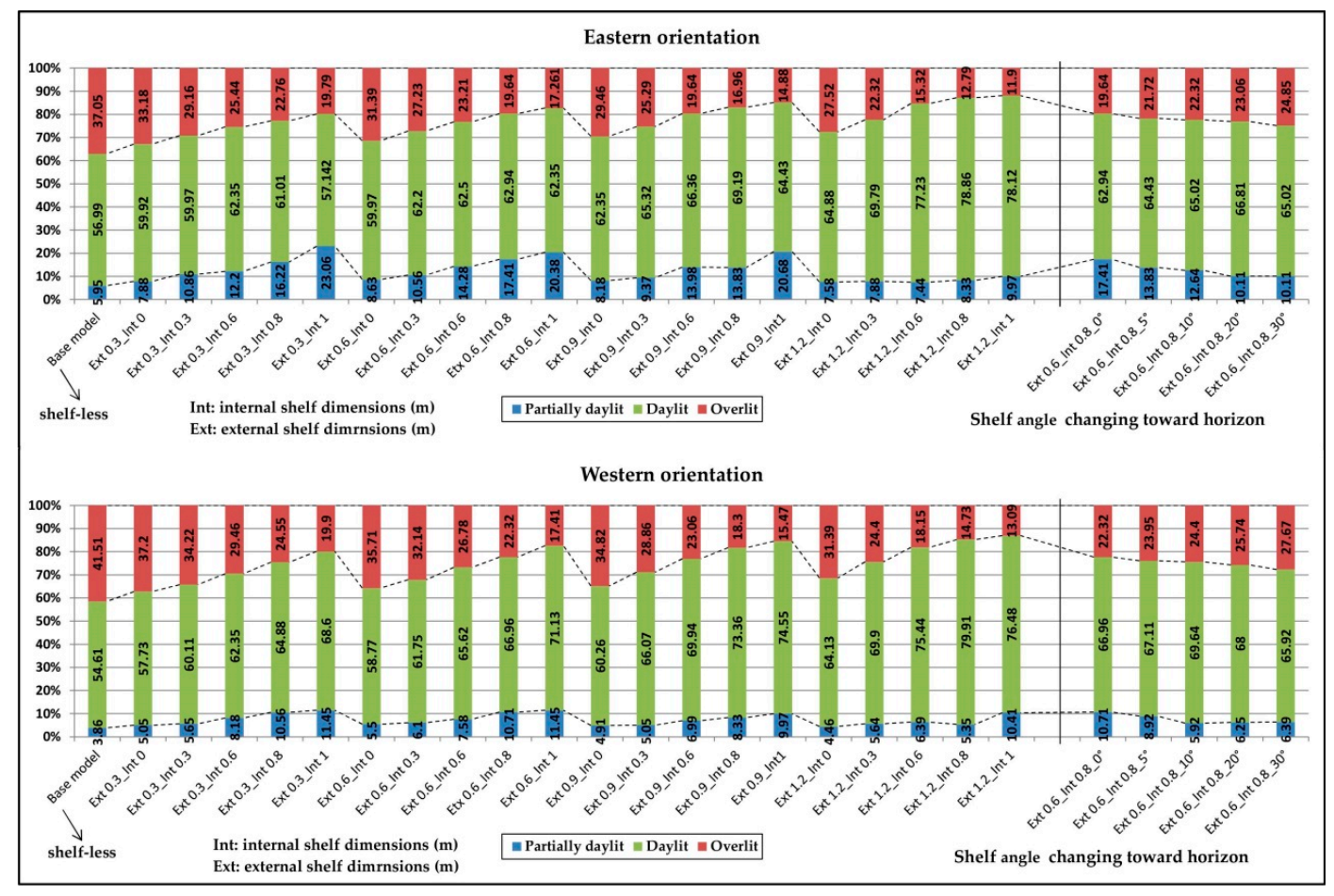

Figure 5. The results of daylight availability analysis for the eastern and western orientations of the light shelf in the three mentioned intervals.

\subsection{Visual Comfort}

Paying attention to the glare phenomenon and controlling it is very important for individuals' visual comfort, especially in educational spaces during the times of having direct sunlight in the internal space. The glare phenomenon was mentioned before in the daylight analysis of the parts having more overlit. These areas have the potential and probability of the glare phenomenon, which interferes with visual comfort. In this part, the areas having the glare probability will be analyzed. Two kinds of glare analyses are presented. In the first analysis, visual comfort is calculated in a determined day and hour of the year by Evaglare software, based on Radiance [45], and is determined based on the DGP index. In the second analysis, the glare probability is predicted annually and calculated by Evaglare software and according to the DGP index [46]. The DGP index is calculated in four intervals. Its results are shown with different colors, including "intolerable glare" (DGP $\geqslant 45 \%$ ), "disturbing glare" $(45 \%>$ DGP $\geqslant 40 \%)$, "perceptible glare" $(40 \%>$ DGP $\geqslant 35 \%)$ and "imperceptible glare" (DGP < 35\%) [47,48]. In annual analysis, all space occupation hours are calculated based on hours. The number of 8760 hours is calculated and shown in the mentioned intervals' format (Figures 6 and 7). For easy and more efficient comparison of light shelf visual comfort, numbers are presented in the mentioned intervals in a percentage format (Figure 8 ). In these two analyses, the human eye level and viewing situation must be determined. Here, the viewer situation and his or her eye level are supposed to be at the middle end part of the room one meter above the floor. The glare analysis is conducted at a single point within the space. Other locations within the space are likely to experience a different number of hours of glare. To calculate glare, because of the higher probability of glare at the south and east facing sides, these two sides are selected at determined hours and by an annual index. The results of southern orientation analysis at 12:00 p.m. of the winter solstice are presented in the upper row of Figure 9 for both the basic shelf-less model and the light shelf. The basic model (shelf-less) has a glare of $33 \%$, and the light shelf model has a glare of $27 \%$ because of the shadow in the middle of the classroom. Of course, it must be noted that in both states, the viewer's eyes are in the shadow and are not in contact with direct sunlight, and when hours change, glaring is more probable. However, for the eastern orientation, the analysis is done at 9:00 a.m. during the winter solstice and is presented in the lower row of Figure 9. The basic model has an insignificant 
glare probability of $24 \%$ because of the smaller angle at 9:00 a.m. during the winter solstice. By adding the light shelf, this amount will decrease to $23 \%$; the glare rate is limited in this orientation, but in the early morning hours, it is more probable.
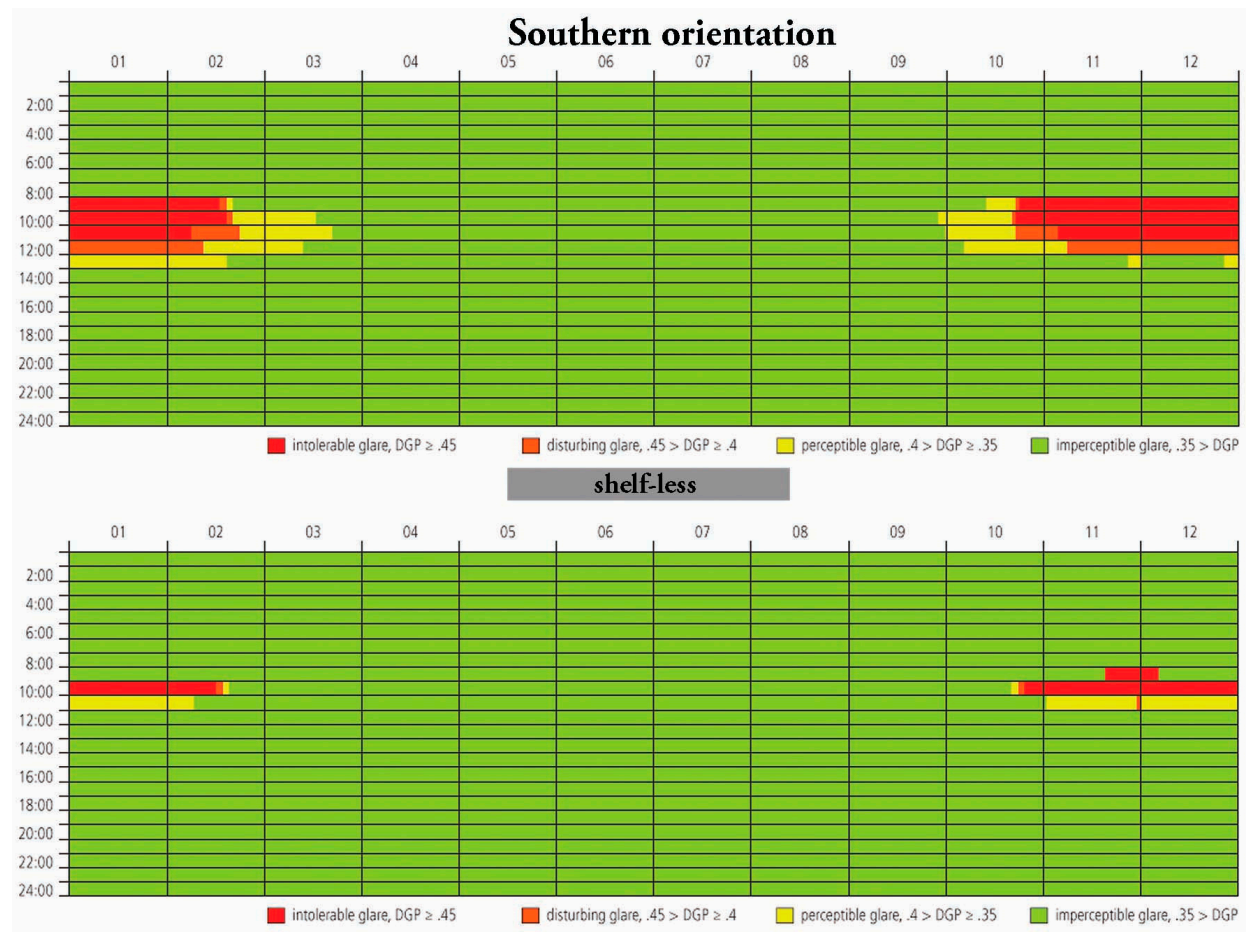

Light shelf Ext: 0.9 Int: 0.8

Figure 6. The results of the annual daylight glare probability sample for the southern orientation.
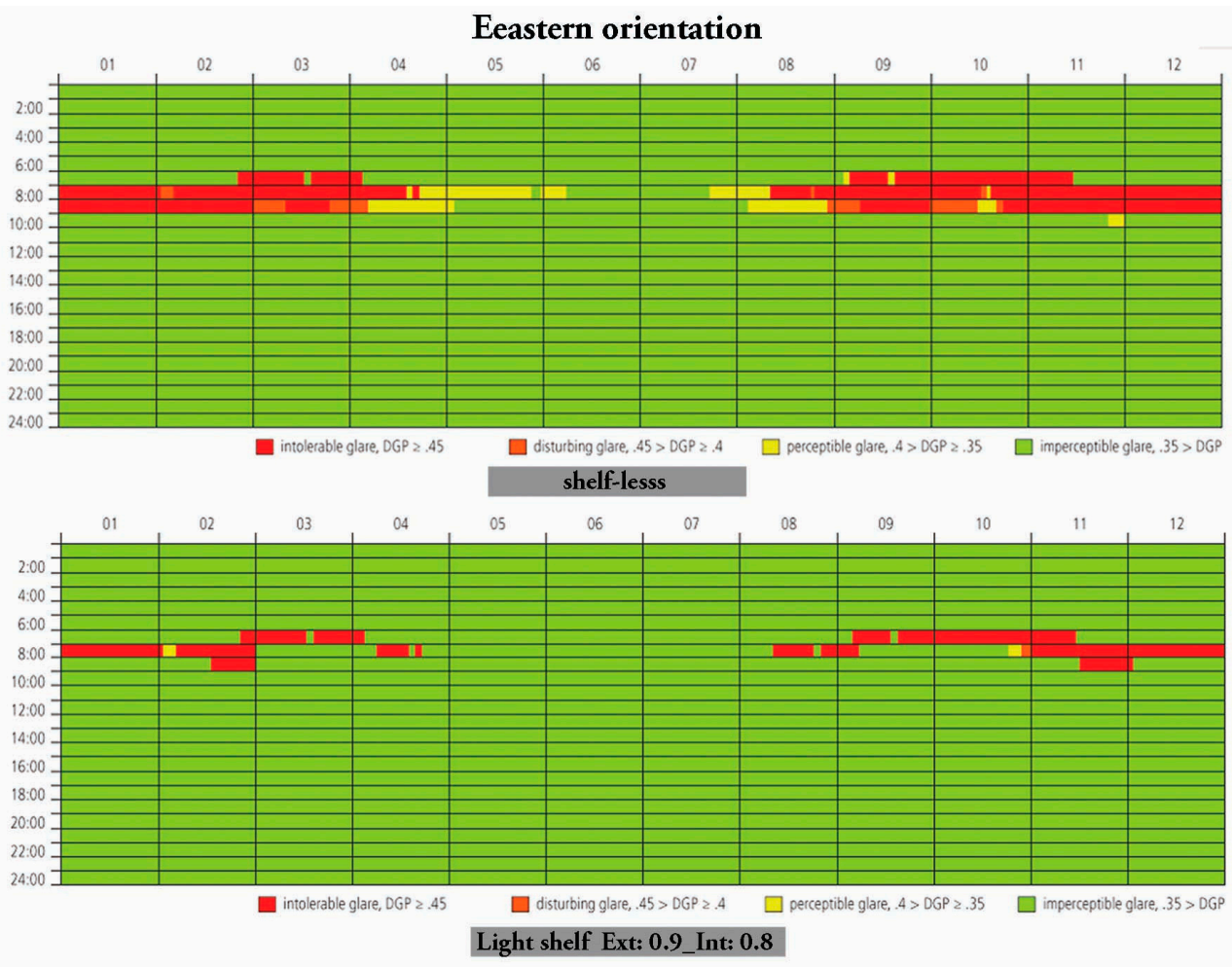

Figure 7. The results of the annual daylight glare probability sample for the eastern orientation, to consider more accurately the few data for the east and west orientation, shown as a percentage in Figure 8 . 


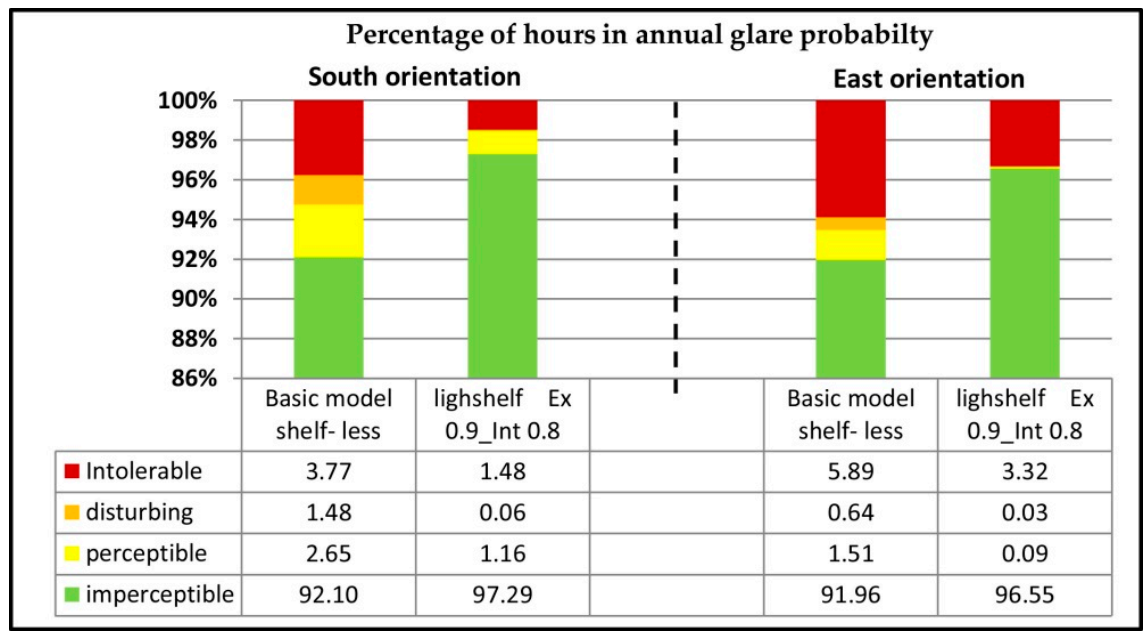

Figure 8. Results percentage of the annual visual comfort analysis with the DGP index, for the southern and eastern orientations, compared to the light shelf and the lack of it during annual hours.

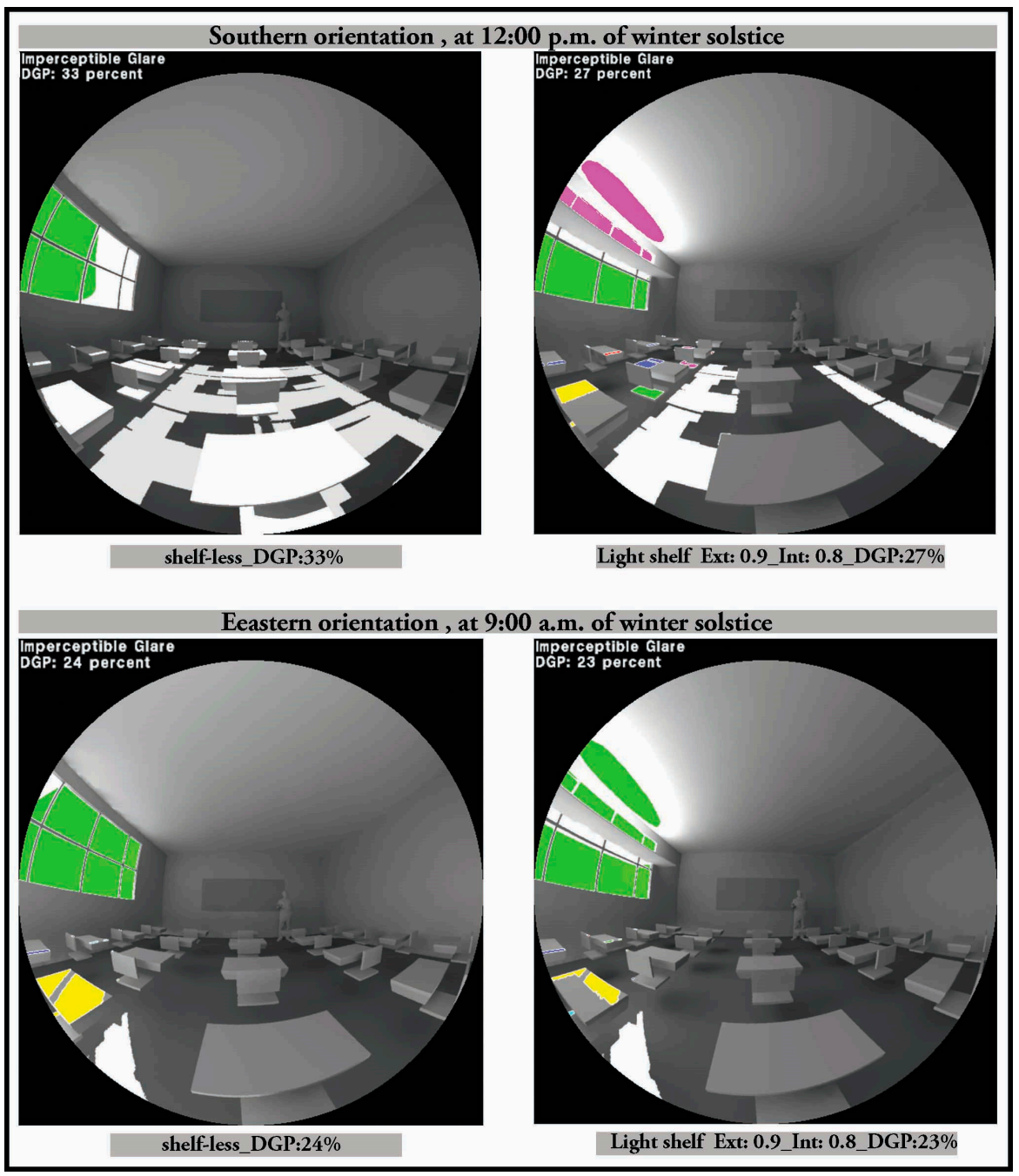

Figure 9. The results of the visual comfort analysis with the DGP index at the middle end part of the room one meter above the floor; southern orientation at 12:00 p.m. of the winter solstice in the upper row; eastern orientation at 9:00 a.m. of the winter solstice in the lower row. 
For exact investigation of light shelf visual comfort, the results are also presented annually to be evaluated in a whole year. As Figure 6 shows, there is intolerable glare at the south-facing side at 9:00 a.m.-12:00 p.m. during the winter when no light shelf is used. However, by adding a light shelf, this glare would be restricted to $10 \mathrm{a} . \mathrm{m}$. in the winter. In addition, the highest amount of intolerable glare at the east-facing side is at 8:00 a.m.-10:00 a.m., except that there is no glare in the summer. Adding a light shelf reduces the amount of intolerable glare mostly occurring at 8 a.m. (Figure 7).

In order to evaluate the number of hours covered by DGP at the south- and east- facing sides more accurately, the calculated data are shown in percentages (Figure 8). As is determined in the following Figure 8, the results of the southern orientation are such that the "intolerable glare" amount of the whole year in the light shelf model is $1.48 \%$ and in the shelf-less model is 3.77\% (this implies a difference of $200 \mathrm{~h}$ ); the amount of "disturbing glare" also decrease a little. Most of this glare is in the southern orientation in winter, which reduces with the light shelf's proper function, because of the small angle of sunshine at 9:00 a.m.-12:00 p.m. In the eastern orientation, also the amount of "intolerable and disturbing glare" will decrease compared to the shelf-less model; the "intolerable glare" amount of the whole year in the light shelf model is $3.32 \%$ and in shelf-less model is $5.89 \%$ (this implies a difference of $225 \mathrm{~h}$ ). Most of the intolerable glare at the east-facing side at 8:00 a.m.-10:00 a.m. depends on the sun altitude during different seasons.

\section{Discussion}

The present study aimed to investigate the influence of a light shelf on daylight performance and visual comfort and achieved significant results in this respect. Unfortunately, the light shelf is not used in Iran, and the importance of daylight is neglected by both construction rules and the groups of architects and designers. In this respect, the results of this study can play an important role in architectural engineering in Iran. Regarding the research questions, the variations of the most important results of simulating 100 different light shelf models were presented. According to Table 4, the series of performance results presented all belong to the daylight and visual comfort.

Table 4. Summary results of the light shelf performance.

\begin{tabular}{|c|c|c|c|c|c|c|c|}
\hline \multirow{3}{*}{ Orientation } & \multicolumn{2}{|c|}{ Light Shelf Length } & \multirow{3}{*}{$\begin{array}{c}\begin{array}{c}\text { External Shelf } \\
\text { Rotation }\end{array} \\
\text { Daylit Area \% } \\
\text { Ext 0.6_Int 0.8 }\end{array}$} & \multicolumn{2}{|c|}{ Point in Time Glare } & \multicolumn{2}{|c|}{ Annual Glare } \\
\hline & \multicolumn{2}{|c|}{ Percent of Daylit Area } & & \multicolumn{2}{|c|}{ DGP \% } & \multicolumn{2}{|c|}{$\begin{array}{l}\text { Percent of Intolerable } \\
\text { Hours (DGP) }\end{array}$} \\
\hline & Shelf_Less & Shelf & & Shelf_Less & Shelf & Shelf_Less & Shelf \\
\hline South & $48 \%$ & $\begin{array}{c}87 \% \\
\text { Ext } 1.2 \_ \text {Int } 1\end{array}$ & $0^{\circ}-76 \%$ & $33 \%$ & $27 \%$ & $3.77 \%$ & $1.48 \%$ \\
\hline North & $70 \%$ & Inappropriate & Inappropriate & \multicolumn{2}{|l|}{ - } & \multicolumn{2}{|c|}{ - } \\
\hline East & $60 \%$ & $\begin{array}{c}78 \% \\
\text { Ext } 1.2 \_ \text {Int } 1\end{array}$ & $10^{\circ}-65 \%$ & $24 \%$ & $23 \%$ & $5.89 \%$ & $3.32 \%$ \\
\hline West & $54.5 \%$ & $\begin{array}{c}80 \% \\
\text { Ext } 1.2 \_ \text {Int } 0.8\end{array}$ & $10^{\circ}-70 \%$ & \multicolumn{2}{|c|}{-} & \multicolumn{2}{|c|}{-} \\
\hline
\end{tabular}

Int: internal shelf dimensions (m); Ext: external shelf dimensions (m).

The light shelf has a better performance at the southern orientation compared to other orientations. By increasing the size of the internal and external light shelves, daylit areas will be distributed more appropriately and will be increased by $40 \%$ compared to the shelf-less conditions. For example, according to Figure 3, (Ext 1.2_Int 1) has 87\% daylit and is the most efficient option with a very good natural light distribution. On the other hand, there are limitations in building internal and external shelves because of their high dimensionality. It addition, they can interfere with classroom conditions. However, even a little increase in the size of internal and external light shelves will result in increased daylight and reduced overlit, and there will be little partial daylit (Figure 3). This increase will also result in the unified suitable distribution of natural light. Considering the design limitations and conditions, designers can use light shelves with suitable dimensions. Regarding the rotation angle of 
the external light shelf to the horizon (Figure 3), the range of allowed changes will be smaller, since at the southern front, a 30-degree angle for the external shelf may result in overlit and disturb visual comfort, especially at larger sunlight angles.

At the southern facade, paying enough attention to visual comfort is very important, especially in educational environments and classrooms. That is why analyzing visual comfort is also important for where we use light shelves. At the initial stage of measuring visual comfort, conducted for a specified date and time, it became clear that the light shelf prevents visual disturbance by creating a shadow (Figure 9). In the annual evaluation and according to the changes in sunlight seasonal direction and severity, notable results were obtained. At the southern orientation (Figure 8), 3.77\% of the time, the annual intolerable glare reaches $1.48 \%$, and the disturbing glare drops to $0.06 \%$ from $1.48 \%$. Additionally, the sum of these values is equal to $330 \mathrm{~h}$ adapted to the occupancy schedule. According to Figure 6, intolerable glare is limited to 10 a.m. in the winter.

Unfortunately, it was not possible to study all cases and all sizes of light shelves and their visual comfort efficiency, since simulating the annual glare is time consuming; furthermore, different sizes of internal and external shelves can have different effects according to the direction of sunlight, especially in the winter. Therefore, we had to confine the calculations to a sample model of the light shelf for the eastern and western orientations. Their impact on visual comfort was clearly observable, although because of their role in breaking the sunlight and creating shadow, all light shelves influence visual comfort. Light shelves are not efficient in the northern orientation. They play the opposite role here, preventing daylight from entering and increasing partial daylit. This is because the north facade does not receive direct sunlight. Here, the best option is not to use light shelves. Without the light shelf, there will be $70 \%$ daylight, while the presence of one will reduce this amount (Figure 4). It must be noted, however, that we used diffuse reflection material for light shelves; materials with a higher degree of reflection, like mirrors, will probably produce different results in the northern orientation.

Daylight performance is relatively the same for eastern and western orientations because of the symmetry of the Sun's east-west movement direction and the amount of time these two fronts receive direct sunlight. As shown in Figure 5, an increase in the size of the light shelf will reduce overlit and increase partial daylit. However, for types of Ext 1.2, we face increasing daylit areas; this might be due to the broad surface for transferring light. Regarding the fact that at the west side, the amount of sunlight in summer is high and disturbing, the light shelf acts as both a light controller and shading, reducing overlit and increasing daylit. This is very important at the west side; however, using openings is not recommended. If needed, the light shelf can act as a controller, especially for distributing daylight, producing shadow near the window and reducing glare. Its performance is however impaired when it comes to transferring daylight to the back of the classroom. The rotation angle of the external light shelf does not play an important role in these two directions.

Visual comfort is very important in eastern and western orientations, especially because of the oblique sunlight. The eastern front was evaluated because it is widely accessed during early hours in the morning. The difference between using shelves or not using shelves (shown at a specific hour in Figure 9) regarding DGP is small, but in calculating the annual amount of glare (Figure 8) for the eastern orientation, the intolerable hours without the light shelf is $5.89 \%$, which reaches $3.32 \%$, with a reduced amount of disturbing glare. The total number of hours is 278 , and the light shelf reduces intolerable and disturbing glare in this orientation. Because of the Sun's movement direction and direct sunlight at the beginning and at the end of the day for the eastern and western orientations, it is very important to be extremely careful in choosing the dimensions and position of the light shelf, so that it does not interfere with visual comfort and proper daylight distribution.

There were limitations in studying the models, since simulating the annual amount of daylight is time consuming, especially in the case of the annual amount of glare. Accordingly, we were limited to studying two cases and comparing them with cases without the light shelf in both orientations. We tried to use large amounts of data, so that the light shelf performance can be studied more conveniently and accurately. Light shelves perform pretty well for the southern orientation, both in 
terms of daylight, causing a unified light distribution, and visual comfort, reducing the number of hours of visual disturbances. Similar studies support these results [9,11,13,16,49-51]. In addition to causing a unified distribution of daylight, light shelves can act as shading; they overshadow half of the window, which does not increase the cooling load in summer nor prevent sunlight from entering in winter. Further research can focus on the role of blinds and shading devices and their combination with light shelves in daylight distribution and energy consumption. In addition, because of different latitudes, the performance of the light shelf can differ in different regions and cities in Iran. This might especially require further research for areas with hot and dry climates or cold climates regarding the buildings' cooling and heating issues.

\section{Conclusions}

The present study aimed to investigate the impact of light shelf geometry parameters on daylight efficiency and visual comfort in different orientations. We used annual and advanced analyses and simulation, in order to obtain visual comfort and a suitable daylight distribution. These simulations consider no interior shades or blinds on the windows, and glare calculations were performed at a single point within the space. One of the most important results was about the light shelf dimensions in the southern orientation. Light shelves are most efficient in the southern orientation; they increase suitable daylight by $2 \%-40 \%$ compared to the shelf-less case. They also reduce the visual mixture: we observed 330 reduced hours of annual glare from the total annual amount of intolerable and disturbing glare. Changes are more restricted in the case of rotation angle for the external light shelf: at the southern side, a 30-degree external light shelf increases overlit, which can disturb visual comfort. It does not perform well at other orientations either. At the northern orientation, light shelves are not efficient because of less direct sunlight, and therefore, increasing the dimensions of the light shelf will result in less suitable daylight. The light shelf can have optimum efficiency in eastern and western orientations: they reduce overlit, but increase the amount of suitable light and partial daylit to the same extent. The light shelf can be efficient at the west side because of the high amount of sunlight: it can prevent too much sunlight and act as a shade overshadowing almost half of the window. Regarding visual comfort in the eastern orientation, the light shelf can reduce disturbing and intolerable glare by $278 \mathrm{~h}$. Regarding daylight in educational environments and the potential of using daylight in Tehran, the results show that light shelves can efficiently distribute daylight and increase visual comfort. Future studies can focus on the role of light shelves in energy and electricity consumption and also light shelves at different latitudes of Iran.

Author Contributions: Mohammad Hossein Moazzeni conducted the simulation and analysis and wrote the manuscript. Zahra Ghiabaklou provided guidance and suggestions.

Conflicts of Interest: The authors declare no conflict of interest

\section{Abbreviations}

The following abbreviations are used in this manuscript:

LBNL Lawrence Berkeley National Laboratory

DGP Daylight Glare Probability

\section{References}

1. Ruck, N. Daylight in Buildings: A Source Book on Daylighting Systems and Components; International Energy Agency: Washington, DC, USA, 2000.

2. Chan, Y.-C.; Tzempelikos, A. Efficient venetian blind control strategies considering daylight utilization and glare protection. Solar Energy 2013, 98, 241-254. [CrossRef]

3. Usgbc. Leed Credit Categories I U.S. Green Building Council. Available online: http://www.usgbc.org/ leed/rating-systems/credit-categories (accessed on 11 April 2014).

4. O'Connor, J.; Lee, E.; Rubinstein, F.; Selkowitz, S. Tips for Daylighting with Windows; Lawrence Berkeley National Laboratory: Berkeley, CA, USA, 1997. 
5. Enermodal Engineering. Daylighting Guide for Canadian Commercial Buildings; Enermodal Engineering: Toronto, ON, Canada, 2002.

6. Boubekri, M. Daylighting, Architecture and Health: Building Design Strategies; Routledge: London, UK, 2008; p. 156.

7. Wohlfarth, H.; Gates, K.S. The effects of color-psychodynamic environmental color and lighting modification of elementary schools on blood pressure and mood: A controlled study. Int. J. Biosoc. Res. 1985, 7, 9-16.

8. Wohlfarth, H.; Sam, C. The effects of color-psychodynamic environment modification upon psycho-physiological and behavioral reactions of severely handicapped children. Int. J. Biosoc. Res. 1982, 3, $10-38$.

9. Almusaed, A. Illuminate by light shelves. In Biophilic and Bioclimatic Architecture; Springer: London, UK, 2011; pp. 325-332.

10. Waary, A.; Hael, T. Enhancing Daylight and Improving Energy Usage through the Utilization of Lightshelves in Deep Plan Office Buildings in Dubai; The British University in Dubai: Dubai, UAE, 2012.

11. Claros, S.-T.; Soler, A. Indoor daylight climate-influence of light shelf and model reflectance on light shelf performance in madrid for hours with unit sunshine fraction. Build. Environ. 2002, 37, 587-598. [CrossRef]

12. Meresi, A. Evaluating daylight performance of light shelves combined with external blinds in south-facing classrooms in athens, greece. Energy Build. 2016, 116, 190-205. [CrossRef]

13. Aghemo, C.; Pellegrino, A.; LoVerso, V.R.M. The approach to daylighting by scale models and sun and sky simulators: A case study for different shading systems. Build. Environ. 2008, 43, 917-927. [CrossRef]

14. Brotas, L.; Rusovan, D. Parametric Daylight Envelope; Sustainable Architecture for a Renewable Future: Munich, Germany, 2013.

15. Ochoa, C.E.; Capeluto, I.G. Evaluating visual comfort and performance of three natural lighting systems for deep office buildings in highly luminous climates. Build. Environ. 2006, 41, 1128-1135. [CrossRef]

16. Lim, Y.-W.; Kandar, M.Z.; Ahmad, M.H.; Ossen, D.R.; Abdullah, A.M. Building façade design for daylighting quality in typical government office building. Build. Environ. 2012, 57, 194-204. [CrossRef]

17. Sanati, L.; Utzinger, M. The effect of window shading design on occupant use of blinds and electric lighting. Build. Environ. 2013, 64, 67-76. [CrossRef]

18. Ochoa, C.E.; Capeluto, I.G. Strategic decision-making for intelligent buildings: Comparative impact of passive design strategies and active features in a hot climate. Build. Environ. 2008, 43, 1829-1839. [CrossRef]

19. Freewan, A.A. Maximizing the lightshelf performance by interaction between lightshelf geometries and a curved ceiling. Energy Convers. Manag. 2010, 51, 1600-1604. [CrossRef]

20. Ponmalar, V.; Ramesh, B. Energy efficient building design and estimation of energy savings from daylighting in chennai. Energy Eng. 2014, 111, 59-80.

21. Kim, G.; Lim, H.S.; Lim, T.S.; Schaefer, L.; Kim, J.T. Comparative advantage of an exterior shading device in thermal performance for residential buildings. Sustain. Healthy Build. 2012, 46, 105-111. [CrossRef]

22. Organization, I.N.S. Guidance School Classroom - Specifications; Institute of Standards \& Industrial Research of Iran: Tehran, Iran, 2002.

23. Organization, I.N.S. School Lighting; Institute of Standards \& Industrial Research of Iran: Tehran, Iran, 2002.

24. Rea, M.S. The Iesna Lighting Handbook: Reference $\mathcal{E}$ Application; Illuminating Engineering Society of North America: New York, NY, USA, 2000; p. 1004.

25. Galasiu, A.D.; Reinhart, C.F. Current daylighting design practice: A survey. Build. Res. Inform. 2008, 36, 159-174. [CrossRef]

26. Ward, G.J. The Radiance Lighting Simulation and Rendering System; ACM: New York, NY, USA, 1994; pp. 459-472.

27. Reinhart, C.F. 4.430 Daylighting; MIT OpenCourseWare Massachusetts Institute of Technology: Cambridge, MA, USA, 2012.

28. Mardaljevic, J. Simulation of annual daylighting profiles for internal illuminance. Light. Res. Technol. 2000, 32, 111-118. [CrossRef]

29. Reinhart, C.F.; Walkenhorst, O. Validation of dynamic radiance-based daylight simulations for a test office with external blinds. Energy Build. 2001, 33, 683-697. [CrossRef]

30. Mardaljevic, J. Verification of program accuracy for illuminance modelling: Assumptions, methodology and an examination of conflicting findings. Light. Res. Technol. 2004, 36, 217-239. [CrossRef] 
31. Reinhart, C.F.; Andersen, M. Development and validation of a radiance model for a translucent panel. Energy Build. 2006, 38, 890-904. [CrossRef]

32. McNeel, R. Associates Rhinoceros Version 5.0, 5; Robert Mc Neel \& Associates: Seattle, WA, USA, 2014.

33. Solemma. Solemma, LLC. Available online: http:/ / www.solemma.net/index.html (accessed on 12 July 2016).

34. Jakubiec, J.A.; Reinhart, C.F. Diva 2.0: Integrating daylight and thermal simulations using rhinoceros 3d, daysim and energyplus. In Proceedings of the Building Simulation 2011: 12th Conference of International Building Performance Simulation Association, Sydney, Australia, 14-16 November 2011.

35. Lagios, K.; Niemasz, J.; Reinhart, C.F. Animated building performance simulation (ABPS)—Linking rhinoceros/grasshopper with radiance/daysim. In Proceedings of SimBuild, New York, NY, USA, 1-3 August 2010.

36. Kim, C.-S.; Seo, K.-W. Integrated Daylighting Simulation into the Architectural Design Process for Museums; Springer: Berlin, Germany, 2012; pp. 325-336.

37. Kim, J. Adaptive façade design for the daylighting performance in an office building: The investigation of an opening design strategy with cellular automata. Int. J. Low-Carbon Technol. 2013. [CrossRef]

38. Sabry, H.; Sherif, A.; Gadelhak, M.; Aly, M. Balancing the daylighting and energy performance of solar screens in residential desert buildings: Examination of screen axial rotation and opening aspect ratio. Sol. Energy 2014, 103, 364-377. [CrossRef]

39. Reinhart, C.F.; Mardaljevic, J.; Rogers, Z. Dynamic daylight performance metrics for sustainable building design. Leukos 2006, 3, 1-25.

40. Anderson, K. Design Energy Simulation for Architects: Guide to 3d Graphics; Routledge: London, UK, 2014; p. 270.

41. Reinhart, C.F.; Wienold, J. The daylighting dashboard-A simulation-based design analysis for daylit spaces. Build. Environ. 2011, 46, 386-396. [CrossRef]

42. Reinhart, C.F.; Weissman, D.A. The daylit area-Correlating architectural student assessments with current and emerging daylight availability metrics. Build. Environ. 2012, 50, 155-164. [CrossRef]

43. Sherif, A.H.; Sabry, H.M.; Gadelhak, M.I. The impact of changing solar screen rotation angle and its opening aspect ratios on daylight availability in residential desert buildings. Sol. Energy 2012, 86, 3353-3363. [CrossRef]

44. Sherif, A.; Sabry, H.; Rakha, T. External perforated solar screens for daylighting in residential desert buildings: Identification of minimum perforation percentages. Sol. Energy 2012, 86, 1929-1940. [CrossRef]

45. Reinhart, C. Daysim. Available online: http://daysim.ning.com/ (accessed on 11 April 2001).

46. Wienold, J.; Christoffersen, J. Evaluation methods and development of a new glare prediction model for daylight environments with the use of ccd cameras. Energy Build. 2006, 38, 743-757. [CrossRef]

47. Wienold, J. Dynamic daylight glare evaluation. In Proceedings of the Building Simulation, Glasgow, Scotland, 27-30 July 2009.

48. Wienold, J.; Christoffersen, J. Towards a New Daylight Glare Rating; Lux Europa: Berlin, Germany, 2005; pp. 157-161.

49. Al-Sallal, K.A. Daylighting and visual performance: Evaluation of classroom design issues in the uae. Int. J. Low-Carbon Technol. 2010, 5, 201-209. [CrossRef]

50. Soler, A.; Oteiza, P. Dependence on solar elevation of the performance of a light shelf as a potential daylighting device. Renew. Energy 1996, 8, 198-201. [CrossRef]

51. Yüksek, İ.; Görgülü, S.; Kocabey, S.; Tuna, M.; Dursun, B. Assesment of daylighting performances of classrooms: A case study in Kirklareli University, Turkey. Light Eng. 2015, 23, 15-24.

(c) 2016 by the authors; licensee MDPI, Basel, Switzerland. This article is an open access article distributed under the terms and conditions of the Creative Commons Attribution (CC-BY) license (http://creativecommons.org/licenses/by/4.0/). 